Bartın Üniversitesi

Eğitim Fakültesi Dergisi

Cilt 6, Sayı 3, s. 1293-1308, Ekim 2017

BARTIN - TÜRKIYE

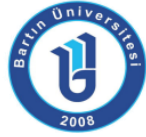

ISSN: 1308-7177
Bartin University

Journal of Faculty of Education

Volume 6, Issue 3, p. 1293-1308, October 2017

BARTIN - TURKEY

\title{
7. Sınıf Çember ve Daire Konusunda Basamaklı Öğretim Uygulamasının Öğrencilerin Matematik Dersine İlişkin Akademik Başarı ve Tutumlarına Etkisi
}

Burcu DUMAN, Yrd. Doç. Dr., Bartın Üniversitesi Eğitim Fakültesi, dmn.brc@gmail.com

ORCID: http://orcid.org/0000-0001-7414-8866

Ceyda ÖZÇELIK, Öğretmen, Bartın Milli Eğitim Müdürlüğü, ceydakara1@gmail.com

ORCID: http://orcid.org/0000-0003-2676-3244

Öz: Araştırmanın amacı, 7. sınıf Çember ve Daire konusunda basamaklı öğretim uygulamasının öğrencilerin matematik dersine ilişkin akademik başarı ve tutumlarına etkisini belirlemektir. Nicel olarak tasarlanan araştırma, deneysel desenlerden öntest - sontest kontrol gruplu desen ile yürütülmüştür. Araştırmanın çalışma grubu, 20162017 eğitim öğretim yılında Bartın ili merkez iMKB Ortaokulu'nda öğrenim gören 22'si deney, 22'si kontrol grubunda olmak üzere toplam 44 öğrenciden oluşmaktadır. Altı hafta süren deneysel işlem sürecinde dersler deney grubunda basamaklı öğretime göre hazırlanan ders etkinlikleriyle, kontrol grubunda ise mevcut programa yönelik uygulamalarla işlenmiştir. Veri toplama aracı olarak akademik başarı testi ve matematiğe yönelik tutum ölçeği kullanıımıştır. Verilerin analizinde SPSS 20.0 programından faydalanıımıştır. Araştırma bulgularına göre; deney ve kontrol gruplarının akademik başarı son test puan ortalamalarında anlamlı bir fark bulunmamaktadır. Deney grubu akademik başarı ön test - son test puan ortalamalarında son test lehine farklııık bulunmaktadır. Deney grubu ön test - son test tutum puan ortalamaları arasındaki anlamlı farklılık son test lehinedir. Deney ve kontrol grupları tutum puan ortalamalarında deney grubu lehine anlamlı bir fark bulunmaktadır. Sonuçlar, basamaklı öğretim uygulamasının mevcut öğretim programına göre öğrencilerin matematik dersine yönelik tutumlarını geliştirmede daha etkili olduğunu göstermektedir. Özellikle matematik dersine karşı olumsuz önyargılara sahip öğrenciler için basamaklı öğretim modeli matematik dersinin farklı kazanımlarını gerçekleştirmek için kullanılabilir. Basamaklı öğretim modelinin farklı bağımlı değişkenler üzerindeki etkisi, öğrenci merkezli çeşitli model ve yöntemlerle desteklenerek araştırılabilir.

Anahtar Kelimeler: basamaklı öğretim, matematik dersi, akademik başarı, tutum.

\section{The Effect of Layered Curriculum Use for the 7th Grade Circle and Circular Region Subject on Academic Success and Attitude towards Mathematics}

\footnotetext{
Abstract: The purpose of this study is to identify the effect of layered curriculum use for the 7th Grade "Circle and Circular Region" subject on academic success and attitude towards Mathematics. In the study designed as a quantitative one, "pretest-posttest experimental design" was used. Participants included 44 students (22 in experimental group, 22 in control group) attending IMKB Secondary School of Bartın during the 2016-2017 school year. The experimental operations of the study lasted for six weeks. Lessons were covered according to the layered curriculum in the experimental group whereas they were covered as it was required by the current curriculum of the school in the control group. As the data collection tool, an academic success test developed by the researchers and the scale of attitude towards Mathematics developed by Önal (2013) were used. For data analysis, SPSS 20.0 statistical package program was utilized. According to the findings, there was a significant difference between pretest -posttest academic success points of experimental and control groups at all sub-dimensions and overall in favor of the posttest.
}

Key Words: layered curriculum, mathematics, academic success, attitude. 


\section{GíRiş}

Yaşadığımız yüzyılda meydana gelen teknolojik gelişmeler neticesinde toplumlar farklı beklentiler içine girmişlerdir. Toplumların bu beklentilerindeki ortak amacı gelişimin gerisinde kalmamak, her alanda söz sahibi olabilmektir. Bu amaçla toplumu oluşturan bireylere verilen önem artmış ve bireylerin eğitimi konusunda farklı arayışlara girilmiştir. Bireylerden, yeri geldiğinde kendilerini olumlu yönde değiştirebilmeleri, sosyal yaşama ayak uydurabilmeleri, kendi kararlarını alabilmede özgürce davranabilmeleri ve karşılaştığı sorunlara değişik bakış açılarıyla çözüm bulabilmeleri beklenmektedir (Kardaş ve Öztürk,2015, 1683). Öte yandan her öğrencinin bilgiyi alma şekli ve hızı farklılık göstermektedir. Bu nedenle, öğrencilerin farklılıklarını göz önüne alarak kalıcı öğrenmeler sağlama noktasında öğretim sürecini farklı model, yöntem ve tekniklerle zenginleştirmek önem kazanmaktadır (Ekici ve Güven, 2013, 204).

Basamaklı öğretim modeli 'her bireyin farklı yollarla öğrendiği ve üst düzey düşünme becerilerini kazanmada, bireysel sorumluluklar aldığı öğretimi düzenleme yolu' olarak tanımlanmaktadır (Nunley, 2004a, 11). Basamaklı öğretim modelinin en belirgin özelliği bireysel çalışma yapan öğrencinin sorumluluk bilinciyle hareket ederek problemlere çözüm bulabilme becerisini kazanmasıdır. Basamaklı öğretim modelinde, öğrencilere konu aşamalı şekilde basitten karmaşığa doğru giden etkinlik ya da ödevlerle sunulur ve öğrencilere seçme hakkı verilir. Öğrenciler her seviyeden seçtikleri görevler içerisinde onlardan beklenen aktiviteleri uygulamak durumundadır. Geniş bir menü içerisinde sunulan öğrenme etkinlikleri sayesinde sürece bütün öğrencilerin aktif katılımı sağlanır (Gün, 2013, 88). Basamaklı öğretim modeli, öğrencilere ödevlerini tamamlamalarına yardımcı çeşitli öğrenme araçları sağlaması bakımından da etkilidir. Bu araçlar, kaydedilmiş derslerden bilgisayar programlarına kadar çok çeşitli teknolojileri içerebilir (Miller, 2004, 659). Basamaklı öğretimde hedefler, üç farklı basamağa ( $A, B$ ve $C$ ) göre belirlenir ve Bloom Taksonomisi'nin bilişsel düzeylerine göre düzenlenir (Demirel, 2015, 229). C basamağında basit ve temel kavramlar, B basamağında karmaşık düşünme gerektiren öğrenmeler, $A$ basamağında ise çok daha karmaşık beceriler ve üst düzey düşünme isteyen uygulamalar yer almaktadır (Nunley, 2003b, 35). illk basamak olan ' $C$ ' basamağı için hazırlanan etkinlik sayısı oldukça fazladır. Bu etkinlikler tüm öğrencilerin yapabileceği düşünülen basit düzeydeki etkinliklerdir. Her etkinliğin önceden belirlenmiş bir puanı vardır. Görevini tamamlayan öğrenci bir üst basamağa geçerken tamamlayamayanlar için ek süre verilmektedir. Bu basamaktaki kavramların iyi bilinmesi diğer basamaklara daha kolay geçilmesine zemin hazırlamaktadır. İkinci basamak olan $\mathrm{B}$ basamağı, $\mathrm{C}$ basamağına göre daha üst düzey görevleri kapsamakta olup Bloom taksonomisinin uygulama basamağını içermektedir. B basamağına, $C$ basamağında öğrenilen bilgilerin uygulama kısmı da denilebilir. Karmaşık etkinliklerin bulunduğu A basamağında, analiz, sentez ve değerlendirme içeren etkinlikler yapılarak öğrencilerden yeni bir ürün ortaya koymaları beklenmektedir (Demirel vd, 2006, 75).

Basamaklı öğretim modelinde öğretim sürecinin değerlendirilmesi; etkinlikler seçilmeden önce öğrencilerin verdikleri sözlü savunmaların değerlendirilmesi, toplanan gelişim dosyalarının değerlendirilmesi ve dereceli puanlama anahtarlarından faydalanılması şeklindedir (Yılmaz ve Gültekin, 2013, 29). Öğrencilerin sözlü savunmada tercih ettikleri etkinliklere bakılarak onların ilgi duydukları alanlar hakkında bilgi sahibi olunabilir ve değerlendirmede kullanılabilir. Aynı şekilde gelişim dosyalarındaki çalışma örneklerinden, ürettikleri modellerden, yazdıkları hikâye ve şiirlerden onların duygusal, bilişsel ve sosyal yönleri hakkında bilgi sahibi olmak mümkündür (Gürbüztürk, 2013, 217-218). Öğretmenler bu süreçte hem öğrencileri daha iyi tanıyabilmekte hem de diğer ünitelere hazırlık aşamasını kolay hale getirebimektedirler. Basamaklı öğretim programının öğrenci merkezli olması, öğrenmeyi etkinliklerle yaparak yaşayarak sağlaması gibi nedenlerden ötürü birçok derste uygulanmaya ve 
denenmeye müsait bir program olduğu söylenebilir. Öğrencilerin çevreleriyle etkileşimlerinde onlara fayda sağlayacak temel bilgi ve becerileri öğretmekte olan matematik eğitimi (MEB, $2009,7)$ yapısı itibariyle basamaklı öğretim uygulamalarıyla daha etkili hale getirilebilir. Nitekim; matematiğin kullanılabilme ve anlaşılabilme ihtiyacının, değişen yaşam şartları içinde önemini arttırdığı ve koruduğu (MEB, 2009, 7) göz önüne alındığında matematik öğretiminde basamaklı öğretim modelinin etkilerinin incelenmesi araştırılmaya değer bir konu olarak görülmektedir.

"Biçim, sayı ve çoklukların yapılarını, özelliklerini ve aralarındaki bağıntıları mantık yoluyla inceleyen, aritmetik, cebir, geometri gibi dallara ayrılan bilim kolu" (TDK, 2017) olarak tanımlanan matematik; sembol ve şekiller temelinde inşa edilmiş evrensel bir dildir. Değişen dünyamızda, matematiği anlayanların ve matematik yapanların, geleceğini şekillendirmede daha fazla seçeneklerinin olacağı açıktır. Matematik eğitimi, öğrenenlere günlük hayatta karşılaşacakları problemleri çözmede akıl yürütmeyi, tahminde bulunmayı, analiz etmeyi gerektirecek bir sistematiklik kazandırmaktadır. Yaratıcı ve eleştirel düşünmeyi gerektirecek ortamlar hazırlayarak öğrencilerin kendi kendilerine öğrenmelerini sağlamaktadır (MEB, 2009, 7). Ellez'e (2004) göre geleneksel öğrenme ortamları öğrencilerin öğrenmeyi sıkıcı bulmasına, ders işlemeye karşı ön yargıı tavır sergilemesine sebep olmaktadır. Aynı şekilde Piht ve Eisenschmidt (2008) öğrencilerin olumsuz tutum yerine olumlu tutum geliştirebilmesi için uygulanan öğretim yöntem ve tekniklerin, öğrencinin yaparak yaşayarak uygulayabileceği, etkin katılım içinde oldukları, bireyselliğe dikkat edilerek gerçekleşmesi gerektiğini belirtmiştir. Uysal(2007)'a göre, özellikle konuların birbiriyle ilişkili olduğu matematik dersine yönelik olumsuz bir tutum geliştirmek, ilerleyen konuların anlaşılmasında öğrenciye zorluk yaşatacağından öğretimin başarısızlıkla sonuçlanmasına neden olmaktadır. Diğer taraftan öğrencilerde matematik dersine karşı korku, dersi sevmeme gibi olumsuz tutumlarla da sıklıkla karşılaşılması sadece bilişssel değil duyuşsal yönden de öğretimin desteklenmesini gerekli kılmaktadır. Öğrencinin seviyesi ve ilgilerine göre bireysel öğretimi esas alan, öğrenciye seçim hakkı tanıyan ve öğrencinin dikkatini ve sorumluluk duygusunu arttırmayı ön plana alan basamaklı öğretim modelinin matematik dersinde öğretimsel hedeflere ulaşma yolunda etkili olabileceği düşünülmektedir. Alanyazında basamaklı öğretim modeli ile ilgili çalışmaların sınırlı ve özelikle Fen Bilimleri dersi kapsamında olması dikkat çekmekte iken (Demirel vd., 2006; Aydoğuş, 2009; Yılmaz, 2010; Gömleksiz ve Biçer, 2012; Durusoy, 2012; Yılmaz ve Gültekin, 2013; Kılınçaslan ve Özdemir Şimşek, 2015) matematik dersinde basamaklı öğretimin etkililiğine yönelik araştırmalar (Yıldırım ve Albayrak; 2017) yok denecek kadar azdır. Bu nedenle, bu araştırmada, eğitim bilimleri alanına katkı sağlayacağı ve bilimsel anlamda önemli bir eksikliği giderme yolunda bir adım teşkil edeceği düşüncesinden hareketle basamaklı öğretim uygulamasının öğrencilerin matematik dersindeki akademik başarı ve matematik dersine yönelik tutumlarına etkisi incelenmiştir.

\subsection{Araştırmanın Amacı}

Araştırmanın amacı, 7. sınıf çember ve daire konusunda basamaklı öğretim uygulamasının öğrencilerin matematik dersine ilişkin akademik başarı ve tutumlarına etkisini belirlemektir. Bu amaç kapsamında aşağıdaki sorulara cevap aranmıştır:

-Deney grubunun ön test - son test akademik başarı puan ortalamaları arasında anlamlı bir fark var mıdır?

-Deney grubunun ön test - son test tutum puan ortalamaları arasında anlamlı bir fark var midır?

-Kontrol grubunun ön test - son test akademik başarı puan ortalamaları arasında anlamlı bir fark var mıdır? 

var mıdır?

-Kontrol grubunun ön test - son test tutum puan ortalamaları arasında anlamlı bir fark

-Deney ve kontrol gruplarının son test akademik başarı puanları arasında anlamlı bir fark var mıdır?

-Deney ve kontrol gruplarının son test tutum puanları arasında anlamlı bir fark var mıdır?

\section{YÖNTEM}

Nicel olarak tasarlanan araştırmada, deneysel desenlerden "öntest - sontest kontrol gruplu desen" kullanılmıştır. Bu desen, yansız atama ile oluşturulan deney ve kontrol gruplarında deney öncesi ve sonrası ölçümlerin yapıldığı durumlarda kullanılmaktadır (Karasar, 2006, 97).

\section{1. Çalışma Grubu}

Araştırmanın çalışma grubu 2016-2017 eğitim öğretim yılında Bartın ili merkez iMKB Ortaokulu'nun 7/C, 7/F ve 7/G sınıflarında öğrenim gören 80 öğrenci arasından seçilmiştir. Öğrencilerin bir önceki yıla ait matematik dersi not ortalamaları ve Arslan ve Gerişli (2015) tarafından geliştirilen öz düzenleme ölçeğine verdikleri cevaplar dikkate alınarak yapılan kümeleme analizi sonucunda ikili atamayla 44 öğrenci çalışma grubuna atanmıştır. Çalışma grupları bir deney bir kontrol grubu olarak belirlenmiştir. Çalışma grubundaki öğrenci sayıları eşit alınarak 22 öğrenci deney, 22 öğrenci ise kontrol grubunda yer almıştır. Hangi öğretim şeklinin hangi gruba uygulanacağı rasgele belirlenmiştir.

\section{2. İşlem}

Deneysel işlem öncesi yapılan ön testlerde deney ve kontrol gruplarının akademik başarı (Mann-Whitney $U=210.00 ; p=0.45$ ) ve matematiğe karşı tutum (Mann-Whitney $U=$ 187.500; $p=0.20$ ) puanları arasında fark çıkmamıştır. Başka bir deyişle deney ve kontrol gruplarının bu iki bağımlı değişken açısından birbirine denk olduğu ortaya çıkmıştır. Araştırmanın deneysel işlemleri altı hafta sürmüştür. Birinci hafta, ön test olarak deney ve kontrol grubu öğrencilerine akademik başarı ve matematiğe yönelik tutum ölçeği uygulanmıştır. Deney grubundaki öğrencilere dersin nasıl işleneceği, ne tür hazırlıklar yapmaları gerekeceği ve basamaklı öğretim hakkında bilgiler verilmiş; sınıf ortamı düzenlenmiştir. Sonraki dört hafta boyunca dersler haftada beş ders saati (toplam 20 ders saati) olmak üzere deney grubunda basamaklı öğretim modeline göre; kontrol grubunda ise mevcut uygulanmakta olan öğretim programının gerektirdiği şekilde işlemiştir. Altıncı hafta, son test olarak deney ve kontrol grubu öğrencilerine akademik başarı testi ve matematiğe yönelik tutum ölçeği tekrar uygulanmıştır.

Deneysel işlemlerde, ortaokul matematik dersi öğretim programı 7. Sınıf düzeyinde yer alan dördüncü ünitedeki "Çember ve Daire" konusuna yönelik üç kazanım esas alınmıştır. Her bir kazanım için beşer saatlik üç ders planı hazırlanmıştır. Deney grubu için hazırlanan planlarda, basamaklı öğretime uygun olarak C, B ve A basamaklarında etkinliklere yer verilmiştir. Öğrenciler seçtikleri etkinlik görevlerini yerine getirmişlerdir. 'Çemberde merkez açıları, gördüğü yayları ve ölçüleri arasındaki ilişkileri belirler' kazanımı için C basamağında 12 , B basamağında 9, A basamağında 6 etkinlik hazırlanmıştır. 'Çemberin ve çember parçasının uzunluğunu hesaplar' kazanımı için $C$ basamağında 11 , B basamağında 9 , A basamağında 3 etkinlik hazırlanmıştır. 'Dairenin ve daire diliminin alanını hesaplar' kazanımı için C basamağında 11 , $B$ basamağında 8 , A basamağında 5 etkinlik hazırlanmıştır. Kazanımlara uygun etkinliklerin yazılmasında ve bu etkinliklerin uygun basamaklara yerleştirilmesinde konu ile ilgili makale ve tez çalışmaları incelenmiş; bir matematik öğretmeni ile matematik eğitimi alanından 
iki ve eğitim programları ve öğretim alanından iki öğretim üyesinin görüşlerine başvurulmuştur. C basamağı etkinliklerinden bazıları şunlardır:

Daire şekliyle ilişkili olabilecek spor türlerinin sınıfta sunma, dairede alan ile ilgili kavramlardan oluşan bir bulmaca hazırlama, daire diliminin alanını gösteren bir afiş hazırlama, daire diliminin alanı ile ilgili bir soruyu resme dönüştürme, çember şekliyle ilişkili olabilecek spor türlerinin sınıfta paylaşılması, çemberde merkez açı ve çevre açı arasındaki farkı gösteren bir tablo hazırlama.

$B$ basamağı etkinliklerinden bazıları şunlardır:

Dairede alan ile ilgili soru kitapçığı hazırlama, daire dilimiyle ilgili drama yapma, pizza maketi üzerinde dilim alanını bulma, öğretmenlerle röportaj yapma, şarkı besteleme, 15 soruluk test çözümü hazırlama, şiir yazma, saat modeli üzerinde dairenin alanlarını gösterme.

A basamağı etkinliklerinden bazıları şunlardır:

Çemberde açı ile ilgili özgün bir hikâye yazma, çemberde açıyla ilgili özgün bir model tasarlama, özgün bir yay modeli oluşturma, haber bülteni hazırlayıp sunma, dergi çıkarma, pi sayısının ispatını gösterme.

Her hafta etkinliklere geçilmeden önce her bir kazanıma ait ön bilgiler sunulmuştur. Etkinlik görevleri C, B ve A basamaklarına ayrılmış halde haftalık olarak yazılı bir liste halinde öğrencilere verilmiştir. Bu listelerde her etkinliğin puanı ve bir üst basamağa geçmek işin gerekli puan da belirtilmiştir. Öğrencilerden belirli sayıda görev seçmeleri ve seçtikleri her görev için ayrıca sözlü savunma yapmaları istenmiştir. Uygulamalar esnasında bir üst basamağa geçemeyen öğrenciler için ek süre verilmiştir. Yapılan bütün etkinlikler ürün dosyasında toplanıp değerlendirme formlarından yararlanılarak puanlanmıştır.

\subsection{Veri Toplama Araçları}

Araştırmada veri toplama aracı olarak araştırmacılar tarafından geliştirilen akademik başarı testi ve Önal (2013) tarafından geliştirilen matematiğe yönelik tutum ölçeği kullanılmıştır. Araştırma kapsamında akademik başarıyı ölçmek amacıyla "Akademik Başarı Testi" geliştirilmiştir. Akademik başarı testi geliştirilirken ortaokul matematik dersi öğretim programı kapsamında yer alan 7. sınıf "Çember ve Daire" alt öğrenme alanına ait kazanımlar esas alınmıştır (Kazanım 1: Çemberde merkez açıları gördüğü yayları ve ölçüleri arasındaki ilişkileri belirler. Kazanım 2: Çemberin ve çember parçasının uzunluğunu hesaplar. Kazanım 3: Dairenin ve daire diliminin alanını hesaplar). Kazanımlar ve hazırlanan belirtke tablosu göz önüne alınarak her biri 4 seçenekli 40 adet çoktan seçmeli test maddesinden oluşan bir taslak form oluşturulmuştur. Taslak form kapsam ve görünüş geçerliliği için bir program geliştirme uzmanı, iki matematik eğitimi alanında uzman öğretim üyesi ve iki ortaokul matematik öğretmeninin görüşü alındıktan sonra pilot uygulama için hazır hale getirilmiştir. Pilot uygulama, I.M.K.B ortaokulunda 8. sınıfa devam eden 60 öğrenci üzerinde gerçekleştirilmiştir. Pilot uygulama sonucu elde edilen veriler üzerindeki test ve madde analizleri için TAP 6.65 programı kullanılmıştır. Yapılan analizler sonucunda maddelerin güçlük ve ayırt edicilik değerleri göz önüne alınarak 15 madde testten çıkarılmış ve 25 maddelik bir akademik başarı testi ortaya çıkmıştır. 25 maddelik bir akademik başarı testinin belirtke tablosu oluşturulmuş ve testte her kazanımı ölçecek soru bulunduğu görülmüştür. Dolayısıyla çıkarılan maddelerden testin kapsam geçerliliği etkilenmemiştir. Akademik başarı testinin ortalama güçlük düzeyi 0.60 , ortalama ayırt ediciliği 0.50 ve güvenirlik katsayısı (KR-20) 0.88 olarak hesaplanmıştır. Sonuçta, orta güçlükte, ayırt ediciliği ve güvenilirliği yüksek bir ölçme aracı elde edilmiştir.

Önal (2013) tarafından geliştirilen "Matematik Dersine Yönelik Tutum Ölçeği" 11'i olumlu ve $11^{\prime}$ i olumsuz olmak üzere 22 maddeden oluşmaktadır. Ölçek, 6., 7. ve 8.sınıf devam eden 311 öğrenci üzerinde geçerlilik ve güvenirlik çalışması yapılarak geliştirilmiştir. İlgi, kaygı, çalışma ve gereklilik olmak üzere dört faktöre sahip olan ölçeğin Cronbach Alpha değeri 0.90 olarak hesaplanmıştır. Bu araştırma kapsamında ise ölçeğin Cronbach Alpha değeri 0.88 olarak 
bulunmuştur. 5'li likert tipinde düzenlenen ölçekteki maddeler "tamamen katılıyorum", "katılıyorum", "kararsızım", "katılmıyorum", ve "kesinlikle katılmıyorum" şeklinde ifadelendirilmiştir.

\subsection{Verilerin Toplanması ve Analizi}

Araştırmada elde edilen verilerin çözümlenmesinde SPSS 20.0 istatistik paket programından yararlanılmıştır. Araştırmada parametrik olmayan istatistikler kullanılmış olup kontrol ve deney grubu öğrencilerinin ön test ve son test sonuçları arasında anlamlı bir fark olup olmadığını belirlemek amacıyla Mann-Whitney U (MWU) Testi yapılımıştır. Kontrol ve deney grubunun kendi içerisinde ön test ve son test sonuçları arasında anlamlı bir fark olup olmadığını belirlemek amacıyla ise Wilcoxon işaretli sıralar testi kullanılmıştır. Verilerin çözümlenmesinde anlamlılık düzeyi 0.05 olarak kabul edilmiştir.

\section{BULGULAR}

Araştırmanın bulguları araştırma sorularına göre sırasıyla sunularak yorumlanmıştır. Tablo 1'de deney grubu ön test -son test akademik başarı puanlarına ilişkin bulgular yer almaktadır.

Tablo 1

Deney Grubu Ön Test -Son Test Akademik Başarı Puanlarına Ilişkin Bulgular

\begin{tabular}{|c|c|c|c|c|c|c|c|}
\hline $\begin{array}{c}\text { Alt } \\
\text { Boyutlar }\end{array}$ & Testler & $\begin{array}{l}\text { Deney } \\
\text { grubu }\end{array}$ & $\mathbf{N}$ & Sıra Ort. & Sıra Top. & $\begin{array}{c}\text { Wilcoxon } \\
\text { (z) }\end{array}$ & $\mathbf{P}$ \\
\hline Hatırlama & $\begin{array}{l}\text { Son Test- } \\
\text { Ön Test }\end{array}$ & $\begin{array}{c}\text { Negatif Sıra } \\
\text { Pozitif Sıra } \\
\text { Eşit }\end{array}$ & $\begin{array}{c}0 \\
22 \\
0\end{array}$ & $\begin{array}{c}0.00 \\
11.50\end{array}$ & $\begin{array}{c}0.00 \\
253.00\end{array}$ & $-4.131 *$ & 0.00 \\
\hline Anlama & $\begin{array}{c}\text { Son Test- } \\
\text { Ön Test }\end{array}$ & $\begin{array}{c}\text { Negatif Sıra } \\
\text { Pozitif Sıra } \\
\text { Eşit }\end{array}$ & $\begin{array}{c}0 \\
22 \\
0 \\
\end{array}$ & $\begin{array}{c}0.00 \\
11.50\end{array}$ & $\begin{array}{c}0.00 \\
253.00\end{array}$ & $-4.121 *$ & 0.00 \\
\hline Uygulama & $\begin{array}{l}\text { Son Test- } \\
\text { Ön Test }\end{array}$ & $\begin{array}{c}\text { Negatif Sıra } \\
\text { Pozitif Sıra } \\
\text { Eşit }\end{array}$ & $\begin{array}{c}0 \\
22 \\
0 \\
\end{array}$ & $\begin{array}{c}0.00 \\
11.50\end{array}$ & $\begin{array}{c}0.00 \\
253.00\end{array}$ & $-4.157^{*}$ & 0.00 \\
\hline Genel & $\begin{array}{c}\text { Son Test- } \\
\text { Ön Test }\end{array}$ & $\begin{array}{c}\text { Negatif Sıra } \\
\text { Pozitif Sıra } \\
\text { Eşit }\end{array}$ & $\begin{array}{c}0 \\
22 \\
0\end{array}$ & $\begin{array}{c}0.00 \\
11.50\end{array}$ & $\begin{array}{c}0.00 \\
253.00\end{array}$ & $-4.114^{*}$ & 0.00 \\
\hline
\end{tabular}

Tablo 1 incelendiğinde deney grubu ön test - son test akademik başarı puanlarında tüm alt boyutlarda (hatırlama; $z=-4.131, p<0.05$, anlama; $z=-4.121, p<0.05$, uygulama; $z=-4.157$, $p<0.05)$ ve test genelinde $(z=-4.114 ; p<0.05)$ son test lehine anlamlı fark olduğu görülmüştür. Bu bulgular basamaklı öğretim uygulamasının, öğrencilerin matematik dersinde akademik başarılarında etkili olduğu şeklinde yorumlanabilir.

Tablo 2'de deney grubu ön test -son test tutum puanlarına ilişkin bulgular yer almaktadır. 
Tablo 2

Deney Grubu Ön Test -Son Test Tutum Puanlarına Iliş̧kin Bulgular

\begin{tabular}{|c|c|c|c|c|c|c|c|}
\hline $\begin{array}{c}\text { Alt } \\
\text { Boyutlar }\end{array}$ & Testler & $\begin{array}{l}\text { Deney } \\
\text { grubu }\end{array}$ & $\mathbf{N}$ & Sıra Ort. & Sira Top. & $\begin{array}{c}\text { Wilcoxon } \\
\text { (z) }\end{array}$ & $\mathbf{P}$ \\
\hline İlgi & $\begin{array}{l}\text { Son Test- } \\
\text { Ön Test }\end{array}$ & $\begin{array}{c}\text { Negatif Sıra } \\
\text { Pozitif Sıra } \\
\text { Eşit }\end{array}$ & $\begin{array}{c}6 \\
15 \\
1\end{array}$ & $\begin{array}{c}5.50 \\
13.20\end{array}$ & $\begin{array}{c}33.00 \\
198.00\end{array}$ & $-2.88^{*}$ & 0.00 \\
\hline Kaygı & $\begin{array}{l}\text { Son Test- } \\
\text { Ön Test }\end{array}$ & $\begin{array}{c}\text { Negatif Sıra } \\
\text { Pozitif Sıra } \\
\text { Eşit }\end{array}$ & $\begin{array}{c}5 \\
13 \\
4\end{array}$ & $\begin{array}{c}12.30 \\
8.42\end{array}$ & $\begin{array}{c}61.50 \\
109.50\end{array}$ & -1.050 & 0.29 \\
\hline Çalışma & $\begin{array}{l}\text { Son Test- } \\
\text { Ön Test }\end{array}$ & $\begin{array}{c}\text { Negatif Sıra } \\
\text { Pozitif Sıra } \\
\text { Eşit }\end{array}$ & $\begin{array}{l}5 \\
9 \\
8 \\
\end{array}$ & $\begin{array}{l}8.80 \\
6.78\end{array}$ & $\begin{array}{l}44.00 \\
61.00\end{array}$ & $-0,546$ & 0.59 \\
\hline Gereklilik & $\begin{array}{l}\text { Son Test- } \\
\text { Ön Test }\end{array}$ & $\begin{array}{c}\text { Negatif Sıra } \\
\text { Pozitif Sıra } \\
\text { Eşit }\end{array}$ & $\begin{array}{c}5 \\
12 \\
5\end{array}$ & $\begin{array}{c}10.80 \\
8.25\end{array}$ & $\begin{array}{l}54.00 \\
99.00\end{array}$ & -1.084 & 0.28 \\
\hline Genel & $\begin{array}{l}\text { Son Test- } \\
\text { Ön Test }\end{array}$ & $\begin{array}{c}\text { Negatif Sıra } \\
\text { Pozitif Sıra } \\
\text { Eşit }\end{array}$ & $\begin{array}{c}2 \\
18 \\
2\end{array}$ & $\begin{array}{c}16.75 \\
9.81\end{array}$ & $\begin{array}{c}33.50 \\
176.50\end{array}$ & $-2.680 *$ & 0.01 \\
\hline
\end{tabular}

Tablo 2 incelendiğinde deney grubu ön test - son test tutum puanlarında ilgi alt boyutu $(z=-2,88 ; p<.005)$ ve ölçek genelinde $(z=-2.680 ; p<0.05)$ son test lehine anlamlı fark görülmektedir. Diğer alt boyutlarda son test lehine artışlar olsa da bu artışlar anlamlı bir fark oluşturmamıştır. Bu bulgular basamaklı öğretim uygulamasının, öğrencilerin matematik dersine yönelik tutumları üzerinde etkili olduğu şeklinde yorumlanabilir.

Tablo 3'de kontrol grubu akademik başarı ön test -son test puanlarına ilişkin bulgular yer almaktadır.

Tablo 3

Kontrol Grubu Akademik Başarı Ön Test -Son Test Puanlarına Ilişskin Bulgular

\begin{tabular}{|c|c|c|c|c|c|c|c|}
\hline $\begin{array}{c}\text { Alt } \\
\text { Boyutlar }\end{array}$ & Testler & $\begin{array}{c}\text { Kontrol } \\
\text { grubu }\end{array}$ & $\mathbf{N}$ & Sira Ort. & Sira Top. & $\begin{array}{c}\text { Wilcoxo } \\
\text { n (z) }\end{array}$ & $\mathbf{P}$ \\
\hline Hatırlama & $\begin{array}{l}\text { Son Test- } \\
\text { Ön Test }\end{array}$ & $\begin{array}{c}\text { Negatif Sıra } \\
\text { Pozitif Sıra } \\
\text { Eşit }\end{array}$ & $\begin{array}{c}0 \\
21 \\
1 \\
\end{array}$ & $\begin{array}{c}0.00 \\
11.00\end{array}$ & $\begin{array}{c}0.00 \\
231.00\end{array}$ & $-4.035^{*}$ & 0.00 \\
\hline Anlama & $\begin{array}{l}\text { Son Test- } \\
\text { Ön Test }\end{array}$ & $\begin{array}{c}\text { Negatif Sıra } \\
\text { Pozitif Sıra } \\
\text { Eşit }\end{array}$ & $\begin{array}{c}0 \\
22 \\
0\end{array}$ & $\begin{array}{c}0.00 \\
11.50\end{array}$ & $\begin{array}{c}0.00 \\
253.00\end{array}$ & $-4.119 *$ & 0.00 \\
\hline Uygulama & $\begin{array}{l}\text { Son Test- } \\
\text { Ön Test }\end{array}$ & $\begin{array}{c}\text { Negatif Sıra } \\
\text { Pozitif Sıra } \\
\text { Eşit }\end{array}$ & $\begin{array}{c}0 \\
21 \\
1\end{array}$ & $\begin{array}{c}0.00 \\
11.00\end{array}$ & $\begin{array}{c}0.00 \\
231.00\end{array}$ & $-4.055^{*}$ & 0.00 \\
\hline Genel & $\begin{array}{l}\text { Son Test- } \\
\text { Ön Test }\end{array}$ & $\begin{array}{c}\text { Negatif Sıra } \\
\text { Pozitif Sıra } \\
\text { Eşit }\end{array}$ & $\begin{array}{c}0 \\
22 \\
0\end{array}$ & $\begin{array}{c}0.00 \\
11.50\end{array}$ & $\begin{array}{c}0.00 \\
253.00\end{array}$ & $-4.117^{*}$ & 0.00 \\
\hline
\end{tabular}

Tablo 3'e göre kontrol grubu ön test - son test akademik başarı puanlarında tüm alt boyutlarda (hatırlama; $z=-4.035, p<0.05$, anlama; $z=-4.119, p<0.05$, uygulama; $z=-4.055$, $p<0.05)$; ve test genelinde $(z=-4.117 ; p<0.05)$ son test lehine anlamlı fark görülmüştür. $B u$ 
bulgular, mevcut öğretim programının gerektirdiği şeklinde işlenen dersin de öğrencilerin akademik başarılarını olumlu yönde etkilediğini göstermektedir.

Tablo 4'de kontrol grubu ön test -son test tutum puanlarına ilişsin bulgular yer almaktadır.

Tablo 4

Kontrol Grubu Ön Test -Son Test Tutum Puanlarına ilişkin Bulgular

\begin{tabular}{|c|c|c|c|c|c|c|c|}
\hline $\begin{array}{c}\text { Alt } \\
\text { Boyutlar }\end{array}$ & Testler & $\begin{array}{c}\text { Kontrol } \\
\text { grubu }\end{array}$ & $\mathbf{N}$ & Sira Ort. & Sira Top. & $\begin{array}{l}\text { Wilcoxon } \\
\text { (z) }\end{array}$ & $\mathbf{P}$ \\
\hline illgi & $\begin{array}{l}\text { Son Test- } \\
\text { Ön Test }\end{array}$ & $\begin{array}{c}\text { Negatif Sıra } \\
\text { Pozitif Sıra } \\
\text { Eşit }\end{array}$ & $\begin{array}{c}11 \\
9 \\
2\end{array}$ & $\begin{array}{l}10.55 \\
10.44\end{array}$ & $\begin{array}{c}116.00 \\
94.00\end{array}$ & -0.412 & 0.68 \\
\hline Kaygı & $\begin{array}{l}\text { Son Test- } \\
\text { Ön Test }\end{array}$ & $\begin{array}{c}\text { Negatif Sıra } \\
\text { Pozitif Sıra } \\
\text { Eşit }\end{array}$ & $\begin{array}{c}15 \\
6 \\
1\end{array}$ & $\begin{array}{c}12.73 \\
6.67\end{array}$ & $\begin{array}{c}191.00 \\
40.00\end{array}$ & -2.640 & 0.05 \\
\hline Çalışma & $\begin{array}{l}\text { Son Test- } \\
\text { Ön Test }\end{array}$ & $\begin{array}{c}\text { Negatif Sıra } \\
\text { Pozitif Sıra } \\
\text { Eşit }\end{array}$ & $\begin{array}{c}6 \\
12 \\
4 \\
\end{array}$ & $\begin{array}{c}11.92 \\
8.29\end{array}$ & $\begin{array}{l}71.50 \\
99.50\end{array}$ & -0.612 & 0.54 \\
\hline Gereklilik & $\begin{array}{c}\text { Son Test- } \\
\text { Ön Test }\end{array}$ & $\begin{array}{c}\text { Negatif Sıra } \\
\text { Pozitif Sıra } \\
\text { Eşit }\end{array}$ & $\begin{array}{c}14 \\
1 \\
7 \\
\end{array}$ & $\begin{array}{l}8.36 \\
3.00\end{array}$ & $\begin{array}{c}117.00 \\
3.00\end{array}$ & $-3.264 *$ & 0.00 \\
\hline Genel & $\begin{array}{c}\text { Son Test- } \\
\text { Ön Test }\end{array}$ & $\begin{array}{c}\text { Negatif Sıra } \\
\text { Pozitif Sıra } \\
\text { Eşit }\end{array}$ & $\begin{array}{c}15 \\
5 \\
3\end{array}$ & $\begin{array}{c}11.04 \\
7.10\end{array}$ & $\begin{array}{c}154.50 \\
35.50\end{array}$ & $-2.396 *$ & 0.02 \\
\hline
\end{tabular}

Tablo 4'e göre kontrol grubu ön test - son test tutum puanlarında gereklilik alt boyutu $(z=-3,264 ; p<0.05)$ ve ölçek genelinde $(z=-2.396 ; p<0.05)$ ön test lehine anlamlı fark görülmektedir. İlgi ve kaygı alt boyutlarında son testlerde düşüşler olsa da bu düşüşler anlamlı bir fark oluşturmamıştır. Çalışma alt boyutunda ise son test lehine olan artış anlamlı bir fark yaratmamıştır. Bu bulgular mevcut öğretim programının, öğrencilerin matematik dersine yönelik tutumlarını düşürdüğü başka bir ifadeyle olumsuz etkilediğini göstermektedir.

Tablo 5'de deney ve kontrol grupları son test akademik başarı puanlarına ilişkin bulgular yer almaktadır.

Tablo 5

Deney ve Kontrol Grupları Son Test Akademik Başarı Puanlarına Ilişkin Bulgular

\begin{tabular}{|c|c|c|c|c|c|c|}
\hline Alt Boyutlar & Gruplar & $n$ & Sira Ort. & Sira Top. & MWU & $\mathbf{P}$ \\
\hline \multirow[t]{2}{*}{ Hatırlama } & Deney & 22 & 24.00 & 528.00 & \multirow{2}{*}{209.000} & \multirow{2}{*}{0.42} \\
\hline & Kontrol & 22 & 21.00 & 462.00 & & \\
\hline \multirow[t]{2}{*}{ Anlama } & Deney & 22 & 25.48 & 560.50 & \multirow{2}{*}{176.500} & \multirow{2}{*}{0.12} \\
\hline & Kontrol & 22 & 19.52 & 429.50 & & \\
\hline \multirow[t]{2}{*}{ Uygulama } & Deney & 22 & 24.64 & 542.00 & \multirow{2}{*}{195.000} & \multirow{2}{*}{0.13} \\
\hline & Kontrol & 22 & 20.36 & 448.00 & & \\
\hline \multirow[t]{2}{*}{ Genel } & Deney & 22 & 25.75 & 566.50 & \multirow{2}{*}{170.500} & \multirow{2}{*}{0.09} \\
\hline & Kontrol & 22 & 19.25 & 423.50 & & \\
\hline
\end{tabular}

Tablo 5' e göre, deney ve kontrol grupları akademik başarı son testlerinde genelde ve tüm alt boyutlarında anlamlı fark görülmemiştir (hatırlama: MWU=209.000; anlama: MWU=176.500; uygulama: $\mathrm{MWU}=195.500$; genel: $\mathrm{MWU}=170.500)$. Anlamlı bir fark 
oluşturmamakla birlikte tüm alt boyut ve genel ortalamalarda deney grubu lehine artışlar meydana gelmiştir. Bu bulgulara göre, hem basamaklı öğretim uygulamasının hem de mevcut öğretim programının öğrencilerin akademik başarılarında olumlu yönde etkisi olduğu; bu etkinin basamaklı öğretim uygulamasının yapıldığı deney grubunda daha fazla olduğu söylenebilir.

Tablo 6 'de deney ve kontrol grupları son test tutum puanlarına ilişkin bulgular yer almaktadır.

Tablo 6

Deney ve Kontrol Grupları Son Test Tutum Puanlarına ilişkin Bulgular

\begin{tabular}{|c|c|c|c|c|c|c|}
\hline Alt Boyutlar & Gruplar & $\mathrm{n}$ & Sira Ort. & Sira Top. & MWU & $\mathbf{P}$ \\
\hline \multirow{2}{*}{ İlgi } & Deney & 22 & 27.45 & 604.00 & \multirow{2}{*}{$133.000 *$} & \multirow{2}{*}{0.01} \\
\hline & Kontrol & 22 & 17.55 & 386.00 & & \\
\hline \multirow[t]{2}{*}{ Kaygı } & Deney & 22 & 26.36 & 580.00 & \multirow{2}{*}{$157.000 *$} & \multirow{2}{*}{0.04} \\
\hline & Kontrol & 22 & 18.64 & 410.00 & & \\
\hline \multirow[t]{2}{*}{ Çalışma } & Deney & 22 & 27.25 & 599.50 & \multirow{2}{*}{$137.500 *$} & \multirow{2}{*}{0.01} \\
\hline & Kontrol & 22 & 17.75 & 390.50 & & \\
\hline \multirow[t]{2}{*}{ Gereklilik } & Deney & 22 & 29.11 & 640.50 & \multirow{2}{*}{$96.500 *$} & \multirow{2}{*}{0.00} \\
\hline & Kontrol & 22 & 15.89 & 349.50 & & \\
\hline \multirow[t]{2}{*}{ Genel } & Deney & 22 & 28.23 & 621.00 & \multirow{2}{*}{$116.000 *$} & \multirow{2}{*}{0.00} \\
\hline & Kontrol & 22 & 16.77 & 369.00 & & \\
\hline
\end{tabular}

Tablo 6 incelendiğinde deney ve kontrol gruplarının son test tutum puanlarında tüm alt boyutlar ve ölçek genelinde deney grubu lehine anlamlı fark olduğu görülmektedir. (illgi: $M W U=133.000$, kaygı: $M W U=157.000$, çalışma: $M W U=137.500$, gereklilik: $M W U=96.500$, ölçek geneli: MWU=116.000 p<0.05). Bu bulgular basamaklı öğretim uygulamasının mevcut öğretim programına göre öğrencilerin matematik dersine yönelik tutumlarını geliştirmede daha etkili olduğunu göstermektedir.

\section{SONUÇ, TARTIŞMA VE ÖNERILER}

Bu araştırma, basamaklı öğretim uygulamasının öğrencilerin matematik dersine ilişkin akademik başarı ve tutumlarına etkisini belirlemek amacıyla gerçekleştirilmiştir. Bu amaçla, ön test son test kontrol gruplu deneysel desen kapsamında deney grubunda dersler basamaklı öğretime; kontrol grubunda ise mevcut öğretim programına göre işlenmiştir.

Araştırma sonuçları, basamaklı öğretim uygulamasının öğrencilerin akademik başarılarını olumlu yönde etkilediği ve arttırdığını göstermektedir. Nitekim Yılmaz'ın $(2010,44)$ ifadesiyle öğrenciye öğrenme sürecinde görevler vererek sorumluluk kazandıran basamaklı öğretim programı, öğrencinin problemleri çözmesinde ve üst düzey fikirler üretmesinde önemli bir yere sahiptir. Kılınçaslan ve Özdemir Şimşek'in (2015) basamaklı öğretim yönteminin ve yaratıcı drama yönteminin etkililiğini deneysel yolla sınadıkları çalışmalarında, basamaklı öğretimin öğrencilerin akademik başarılarını olumlu yönde etkilediği sonucuna ulaşılmıştır. Gömleksiz ve Biçer'in (2012) araştırma sonuçlarında da akademik başarının basamaklı öğretim programının uygulandığı deney grubu lehine farklılaştığı görülmüştür. LaSovage'in (2006) yüksek lisans tezinde de basamaklı öğretim programına dayalı öğretim başarılı sonuçlar vermiştir. Ayrıca, Hançer ve Yalçın (2009) ve Baytok (2007) yapılandırmacı yaklaşıma dayalı araştırmalarında öğrencilerin ilgi ve düzeyine uygun öğretimin öğrencilerin akademik başarılarını arttırdığı sonucuna ulaşmışlardır.

Mevcut öğretim programına göre ders işlenen grubun akademik başarılarının da arttığı görülmüştür. Söz konusu konuların derslerde daha önce işlenmemiş olmasından dolayı bu artış, normal ve beklenen bir sonuç olarak nitelendirilebilir. Gömleksiz ve Biçer'in (2012) araştırma 
sonuçlarında da kontrol gruplarının her birinin akademik başarı testinin bilgi ve kavrama basamakları ile testin tümünden aldıkları sontest puan ortalamaları öntest puan ortalamalarından daha yüksek çıkmıştır.

Deneysel uygulama sonunda grupların akademik başarıları arasında anlamlı farklılık görülmemiştir. Deney grubunun akademik başarı düzeyi kontrol grubundan daha yüksek olsa da bu durum farklılık oluşturmamıştır. Akademik başarı testinin hatırlama, anlama ve uygulama seviyesinde sorular içermesi, kontrol grubu için de soruları kolay cevaplanabilir duruma getirmiş olabilir. Bu çıkarımla ilgili olarak Gömleksiz ve Biçer'in (2012) araştırma sonucuna bakmak tartışmaya katkı getirebilir. Çünkü söz konusu araştırmada kontrol grubunun uygulama, analiz ve değerlendirme basamaklarındaki öntest-sontest puan ortalamaları arasında anlamlı farklııı bulunmadığı; grupların uygulama, analiz ve değerlendirme basamaklarındaki son test puan ortalamalarının ise deney grubu lehine farklılaştığı görülmüştür. Öte yandan, bu sonuç, Aydoğuş'un (2009) bulguları ile örtüşmemektedir. Genel olarak grupların akademik başarıları arasındaki farklılığın olmaması başarı testinin değerlendirme, çözümleme, yaratma gibi üst düzeylerde sorular içermemesinden kaynaklanıyor olabilir.

Basamaklı öğretim uygulaması, öğrencilerin matematik dersine ilişkin tutumlarını genel anlamda olumlu yönde değiştirmiştir. Ayrıca, basamaklı öğretim uygulamasının derse olan ilgiyi de arttırdığı ortaya çıkmıştır. Akdemir (2006) öğrencilerin matematiğe ilişkin olumlu ya da olumsuz bir tutum sergilemelerinin sahip oldukları ders tecrübeleriyle birlikte değişim gösterdiğini belirtmektedir. Bu açıdan ilgi ve tutumun artmasında, basamaklı öğretimin esnek yönünü ifade eden; öğrencilerin istekleri doğrultusunda etkinlik önerebilmeleri ve seçebilmelerine fırsat tanınması başka bir deyişle etkinlikleri seçme aşamasında özgür bırakılmalarının etkisi olduğu düşünülmektedir. Benzer şekilde Öner (2012) tarafından sosyal bilgiler dersinde yürütülen araştırmada, çoklu zekâ kuramı destekli basamaklı öğretim uygulamasının öğrencilerin derse yönelik tutumlarını olumlu yönde etkilediği ortaya çıkmıştır. Kılınçaslan ve Özdemir Şimşek (2015)'in gerçekleştirdikleri araştırmanın nitel bulguları 6. sınıf fen ve teknoloji dersi "Kuvvet ve Hareket" ünitesinde basamaklı öğretim yönteminin, derse olan ilgiyi arttırdığı yönündedir. Gömleksiz ve Biçer (2012)'in araştırmasında basamaklı öğretimin fen ve teknoloji dersine yönelik öğrenci tutumları üzerindeki etkisinin olumlu olduğu ortaya konulmuştur. Diğer taraftan, Demirel vd, (2006), Yılmaz (2010) ve Durusoy (2012) un araştırmalarındaki basamaklı öğretim uygulamasının öğrencilerin Fen ve Teknoloji Dersine yönelik tutumları üzerinde istatistiksel olarak anlamlı fark oluşturmadığının bulunması bu araştırma sonuçlarıyla örtüşmemektedir.

Kontrol grubunun uygulama sonrası tutum puanlarında düşüş görülmüştür. Bu sonuç, Yıldırım ve Albayrak (2017)'ın matematik dersi "alan ölçme" konusunda düz anlatım ve soru cevap yöntemleri ile basamaklı öğretimi karşılaştırdıkları çalışmalarıyla örtüşmektedir. Söz konusu araştırmada da kontrol gruplarının tutum son test puanlarında düşüş gözlenmiş ve bu duruma neden olarak düz anlatım ve soru cevap yöntemlerinin öğrenci motivasyonu üzerindeki olumsuz etkilerinin yanı sıra öğretimi gerçekleştirilen alan ölçme konusunun zorluk düzeyi gösterilmiştir.

Bu çalışmada, deney ve kontrol gruplarının son test tutum puanları karşılaştırıldığında gruplar arasında anlamlı bir fark görülmüştür. Ölçek geneli ve tüm alt boyutlarında matematiğe yönelik tutum geliştirmede deney grubu lehine artışlar olmuştur. Bu sonuç, basamaklı öğretim uygulamasının mevcut öğretim programına göre öğrencilerin matematik dersine yönelik olumlu tutum geliştirmelerinde daha etkili olduğunu göstermektedir. Bu durum, basamaklı öğretimin bireysel farklılıkları esas alan öğrenci merkezli bir anlayışla öğrencilerin ilgi ve istekleri doğrultusunda gerçekleştirebildikleri etkinliklerin etkisiyle açıklanabilir. Ayrıca, öğrencilerin ihtiyaç duyduğu süre verilerek basitten zora doğru adım adım 
ilerleyerek başarı duygusunu tadan öğrencilerin motivasyonlarının yükseldiği düşünülmektedir. Başbay $(2005,99)$ 'a göre basamaklı öğretim, öğrencilerin etkinlik hazırlarken diğerleriyle aralarında olan hız farkı sebebiyle derse olan ilgilerinin azalmasını da engellemektedir. Dolayısıyla basamaklı öğretim uygulamaları öğrencilerin tutumlarını olumlu yönde etkilemektedir. Yıldırım ve Albayrak (2017)'ın araştırmasında da basamaklı öğretim yönteminin öğrencilerin tutumları üzerinde düz anlatım ve soru cevap yöntemlerine göre daha olumlu etkilere sahip olduğu ortaya çıkmıştır. Bu araştırmalardan farklı olarak Demirel vd. (2006) tarafından yapılan çalışmada basamaklı öğretime ve geleneksel öğretimin öğrenci tutumları üzerinde benzer etkiye sahip olduğu bulunmuştur. Bu sonucun ortaya çıkmasında, hem deney hem de kontrol gruplarının ön test tutum puanlarının yüksek olmasının etkisi olduğu ifade edilmiştir.

$\mathrm{Bu}$ araştırma sonucunda basamaklı öğretim uygulamasının akademik başarı ve tutumu olumlu yönde etkilediği ortaya çıkmıştır. Bu nedenle öğretim sürecinde çeşitli derslerde, farklı sınıf düzeylerinde, farklı kazanımları gerçekleştirmeye yönelik olarak basamaklı öğretim uygulamalarına yer verilmesi faydalı olabilir. Bunu desteklemek adına öğretmen kılavuz kitapları ile öğrenci ders ve çalışma kitaplarında basamaklı öğretim uygulamalarına yer verilebilir. Araştırmada akademik başarı hatırlama, anlama ve uygulama boyutlarında ele alınmıştır. Yapılacak diğer araştırmalarda basamaklı öğretim uygulamalarının etkileri çözümleme, değerlendirme ve yaratma gibi bilişsel alanın üst basamaklarını içeren ölçme araçları kullanılarak araştııılabilir. Basamaklı öğretimin çeşitli öğrenci merkezli yöntem ve tekniklerle ilişkilendirilerek öğrenme-öğretme sürecine katkısı incelenebilir.

\section{KAYNAKLAR}

Akdemir, Ö. (2006). Ilköğretim öğrencilerinin matematik dersine yönelik tutumları ve başarı güdüsü. (Yayımlanmamış yüksek lisans tezi). Dokuz Eylül Üniversitesi, İzmir.

Aydoğuş, R. (2009). Ilköğretim 6. ve 7. sınıf fen ve teknoloji dersinde basamaklı öğretim yönteminin akademik başarıya etkisi. (Yayımlanmamış yüksek lisans tezi). Afyon Kocatepe Üniversitesi, Afyon.

Başbay, A. (2005). Basamaklı öğretim programıyla desteklenmiş proje tabanlı öğrenme yaklaşımının öğrenme sürecine etkileri. Ege Eğitim Dergisi, 6(1), 95-116.

Baytok, H. (2007). Yapılandırmacı öğrenme kuramına dayalı öğretimin ilköğretim 7. sınıf basınç konusunda öğrenci başarısı ve tutumuna etkisi. (Yayımlanmamış yüksek lisans tezi). Balıkesir Üniversitesi, Balıkesir.

Biçer, S. (2011). Fen ve teknoloji dersinde basamaklı öğretim yönteminin öğrenci başarısına, kalıcılığa ve tutumlarına etkisi. (Yüksek lisans tezi). Fırat Üniversitesi, Elazı̆̆.

Demirel, Ö. (2015). Eğitimde program geliştirme (24.baskı). Ankara: PegemA Yayıncılık

Demirel, Ö., Şahan, H. H. vd. (2006). Basamaklı öğretim programının süreç ve ürün açısından değerlendirilmesi. Milli Eğitim Dergisi, 172, 72-90

Durusoy, H. (2012). 6.sınıf "Kuvvet ve Hareket" ünitesinde basamaklı öğretim yöntemi ve yaratıcı drama yönteminin öğrenci erişisine ve kalıcılığa etkisi. (Yüksek lisans tezi). Hacettepe Üniversitesi, Ankara.

Ekici, G. ve Güven, M. (2013). Ögrenme ögretme yaklasimlari ve uygulama örnekleri. Ankara: Pegem Akademi. 
Ellez, A. M. (2004). Etkin öğrenme, strateji kullanım, matematik başarısı, güdü ve cinsiyet ilişkileri. (Yayımlanmamış doktora tezi), Dokuz Eylül Üniversitesi, İzmir.

Gömleksiz, M. N. ve Biçer, S. (2012). Fen ve teknoloji dersinde basamaklı öğretim programının öğrenci başarısına, kalıclığa ve tutumlarına etkisi. International Journal of Human Sciences [Online], (9)2, 1657-1683.

Gün, E. S. (2013). The Reflections of layered curriculum to learning-teaching process in social studies course. International Journal of Instruction. 6(2), 87-98.

Gürbüztürk, O. (2013). Basamaklı öğretim programı. (Ed. G. Ekici ve M. Güven). Öğrenme öğretme yaklaşımları ve uygulama örnekleri (1.Baskı). Ankara: Pegem Yayınevi.

Hançer, A. H. ve Yalçın, N. (2009). Fen eğitiminde yapılandırmacı yaklaşıma dayalı bilgisayar destekli öğretimin akademik başarı ve kalıcılığa etkisi. Cumhuriyet Üniversitesi Sosyal Bilimler Dergisi, 33(1), 75-88.

Karasar, N. (2006). Bilimsel araştırma yöntemleri (16.Baskı). Ankara: Nobel Yayınları.

Kardaş, M. N ve Öztürk, Y. (2015). Aktif öğrenme tekniklerinin türkçe öğretiminde başarı tutum ve uygulamalara yönelik öğrenci görüşleriyle ilişkisi: bir meta- analiz çalışması. International Journal of Languages' Education and Teaching UDES, 1682- 1692.

Kılınçaslan, H. ve Özdemir Şimşek, P. (2015). 6. sınıf "Kuvvet ve Hareket" ünitesinde basamaklı öğretim yöntemi ve yaratıcı drama yönteminin erişiye, tutuma ve kalıcılığa etkisi. Eğitim ve Bilim, 40 (180), 217-245.

LaSovage, A. J. (2006). Effect of using a layered curriculum format of instruction in a high school environmental science energy unit. Michigan State University.

MEB. (2009). Ilköğretim matematik dersi 6- 8. sınıflar öğretim programı ve kılavuzu. Ankara: MEB.

Miller, A. (2004). Brain-based learning with technological support. Association for Educational Communications and Technology, 27, 658-662.

Nunley, K. F. (2003a). Giving credit where credit is due. Principal Leadership, 3-9.

Nunley, K. (2003b). Layered curriculum brings teachers to tiers. Principal Leadership, 69 (1), 3136.

Nunley, F.K. (2004).Layered curriculum. Amherts: Brains.org Publication.

Önal, N. (2013). Ortaokul öğrencilerinin matematik tutumlarına yönelik ölçek geliştirme çalışması. Illköğretim Online. 12(4), 938-948.

Öner, Ü. (2012). Sosyal bilgiler dersinde çoklu zekâ kuramı destekli basamaklı öğretim programının öğrencilerin akademik başarısına, tutumlarına ve kalıcılığa etkisi. (Yayımlanmamış doktora tezi). Atatürk Üniversitesi, Erzurum.

Piht, S. \& Eisenschmidt, E. (2008). Pupils' attitudes toward mathematics: Comparative research between Estonian and Finnish practice schools. Problems of Education in the 21st Century, 9, 97-106.

TDK (2017). Türk Dil Kurumu Güncel Türkçe Sözlük. http://tdk.gov.tr.

Uysal, O. (2007). Ilköğretim II. kademe öğrencilerinin matematik dersine yönelik problem çözme becerileri, kaygıları ve tutumları arasındaki ilişkilerin değerlendirilmesi. (Yayımlanmamış yüksek lisans tezi). Dokuz Eylül Üniversitesi, İzmir. 
Yıldırım, Z ve Albayrak, M. (2017). Matematik dersinde basamaklı öğretim yönteminin kullanılmasının öğrencilerin duyuşsal gelişimlerine etkisi. Atatürk Üniversitesi Kazım Karabekir Eğitim Fakültesi Dergisi, 34, 133-154.

Yılmaz, F. (2010). Fen ve teknoloji dersinde basamaklı öğretim programı uygulamaları. (Yayınlanmamış doktora tezi). Anadolu Üniversitesi, Eskişehir.

Yılmaz, F. ve Gültekin, M. (2013). Fen ve teknoloji dersinde basamaklı öğretim programı uygulamaları. Journal of Computer and Education Research, 1(1), 27-59. 


\section{SUMMARY}

The purpose of this study is to identify the effect of layered curriculum use for the 7th Grade "Circle and Circular Region" subject on academic success and attitude towards Mathematics. Within the scope of this purpose, answers to the following questions were sought:

Is there a significant difference between pretest posttest academic success point averages of the experimental group

Is there a significant difference between pretest and posttest attitude point averages of the experimental group?

Is there a significant difference between pretest and posttest academic success point averages of the control group?

Is there a significant difference between pretest and posttest attitude point averages of the control group?

Is there a significant difference between the posttest academic success points of experimental and control groups?

Is there a significant difference between the posttest attitude points of experimental and control groups?

In the study designed as a quantitative one, "pretest-posttest experimental design" was used. Participants included 44 students (22 in experimental group, 22 in control group) attending IMKB Secondary School of Bartın during the 2016-2017 school year. In the pretests applied before experimental operations, no difference was found between the points of academic success and attitude towards Mathematics of experimental and control groups. In other words, it was concluded that experimental and control groups were equivalent to each other in terms of those two dependent variables. The experimental operations of the study lasted for six weeks. Lessons were covered according to the layered curriculum in the experimental group whereas they were covered as it was required by the current curriculum of the school in the control group. In the experimental operations, three learning outcomes related to "Circle and Circular Region" subject in the fourth unit of 7th grade Mathematics lesson were taken as a basis. For each outcome, three five-hour lesson plans were prepared. The plans for experimental group included activities in C, B, and A layers of layered curriculum.

Activity tasks were given to students as a weekly written list divided into C, B and A layers. In those lists, points for each activity and necessary points to proceed to the upper layer were indicated. Students were asked to choose a specific number of tasks and to plead for each task they chose. During the implementations, those students who were not able to proceed to the upper level were granted an extension of time. All the activities were collected in a product file and graded with the help of evaluation forms.

As the data collection tool, an academic success test developed by the researchers and the scale of attitude towards Mathematics developed by Önal (2013) were used. The average difficulty level of the 25-item academic success test was calculated as 0.60 , the distinctiveness as 0.50 and reliability coefficient as (KR-20) 0.88. Consequently, an assessment instrument of medium difficulty with high levels of distinctiveness and reliability was achieved. "The scale of attitude towards Mathematics" comprised of 22 items (11-negative, 11-positive) and four factors as attention, anxiety, labor and necessity. For data analysis, SPSS 20.0 statistical package program was utilized.

According to the findings, there was a significant difference between pretest -posttest academic success points of experimental and control groups at all sub-dimensions and overall in favor of the posttest. In the pretest-posttest attitude points of the experimental group, a significant difference was found in the sub-dimension of attention and overall in favor of the posttest. In the pretest-posttest attitude points of the control group, there found to be a significant difference overall in favor of the pretest, which showed that current curriculum had adverse effects on the attitude of students towards Mathematics. In the academic success posttests of experimental and control groups, no significant difference was found at sub-dimensions and overall. This result indicated that both layered curriculum and the current curriculum affected the students' academic success positively. In the posttest attitude points of experimental and control groups, a significant difference occurred at all sub-dimensions and 
overall in favor of the experimental group, which revealed that layered curriculum was more effective than the current curriculum in developing the attitude of students towards Mathematics. Layered curriculum can be used especially for those students who are negatively prejudiced against Mathematics to realize different learning outcomes of the lesson. Moreover, the effect of layered curriculum on different dependent variables can be searched with the support of various student-centered models and methods. 


\section{Uygulamaya Ait Bazı Fotoğraflar}

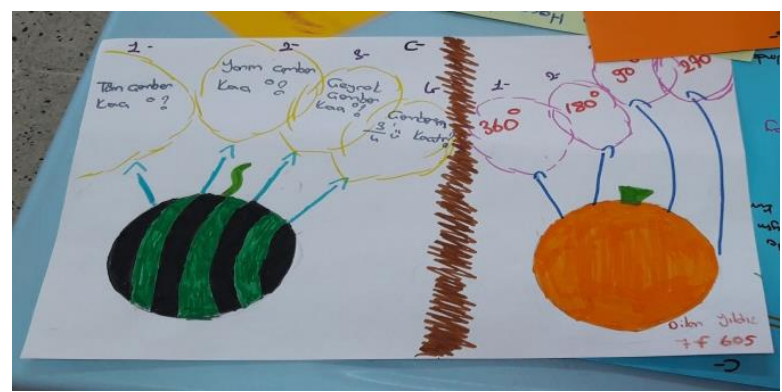

Daire diliminin alanı ile ilgili bir soruyu resme dönüştürme

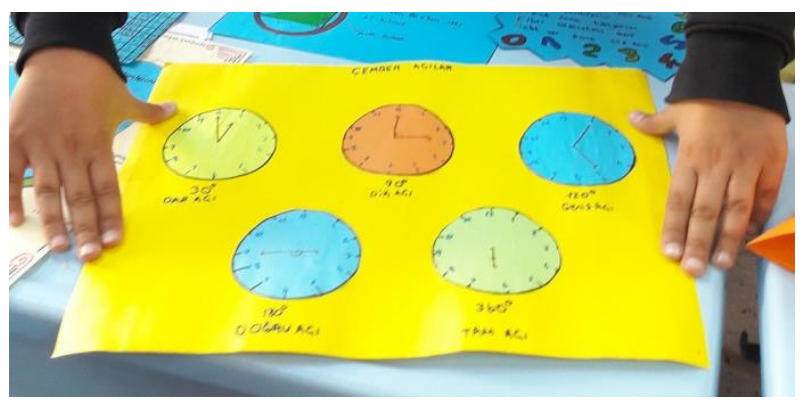

Saat modeli üzerinde dairenin alanlarını gösterme

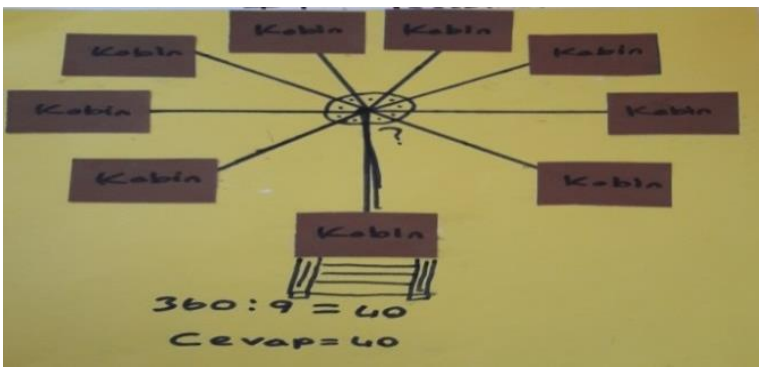

Dönme dolap kabinlerinin merkez açılarının bulunması

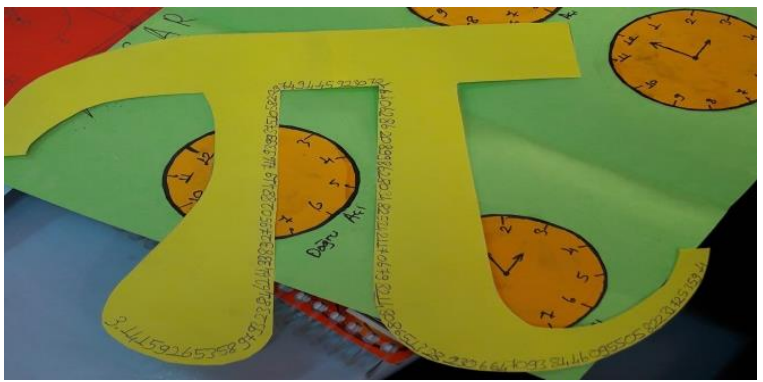

Pi sayısının modelle gösterilmesi 